\title{
GROWTH, NUTRIENT UPTAKE AND YIELD OF SOYBEAN AS INFLUENCED BY PHYTASE ENZYME AND FYM LEVELS IN NON-CALCAREOUS SOIL
}

\author{
A. B. JADHAV ${ }^{*}$, R. K. SURADKAR ${ }^{2}$, A. V. PATIL ${ }^{3} \&$ J. M. KHIRE ${ }^{4}$ \\ ${ }^{I}$ Division of Soil Science and Agricultural Chemistry, College of Agriculture, Pune, Maharashtra, India \\ ${ }^{2}$ Scholar Department of Soil Science and Agricultural Chemistry, MPKV, Rahuri, Maharashtra, India \\ ${ }^{3}$ Assistant Professor of Soil Science and Agricultural Chemistry, Maharashtra, India \\ ${ }^{4}$ Senior Scientist, NCIM, NLC, Pune, Maharashtra, India
}

\begin{abstract}
A pot culture experiment was conducted to assess the "Nutrient uptake and yield of soybean as influenced by phytase and FYM levels in non calcareous soil" during Kharif 2014 at Division of soil Science and Agricultural Chemistry, College of Agriculture, Pune. The treatment consisted of four levels of each phytase (0, 1200, 2400 and 3600 IU) and FYM (0, 2.5, 5, $\left.7.5 \mathrm{tha}^{-1}\right)$ replicated thrice in factorial randomized block design. Yield and nutrient uptake was assessed at $50 \%$ flowering and harvest of soybean. Yield or dry matter production was found significantly influenced with the application of phytase

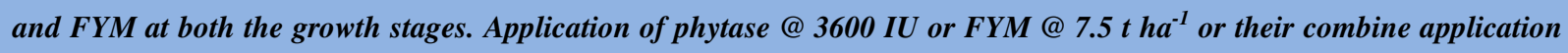
reported significantly higher plant height, root length, root shoot ratio, fresh and dry weight of roots, number and weight of root nodules than rest of the treatment. Significantly higher mean straw yield was recorded with the application of phytase @ $3600 \mathrm{IU}$ (12.86 and $\left.14.31 \mathrm{~g} \mathrm{pot}^{-1}\right)$ at $50 \%$ flowering and at harvest. Significantly higher grain and straw yield was recorded with the application of phytase@3600 IU (17.34 and $\left.14.31 \mathrm{~g} \mathrm{pot}^{-1}\right)$ which was statistically at par with phytase@ $2400 \mathrm{IU}\left(17.28\right.$ and $\left.13.74 \mathrm{~g} \mathrm{pot}^{-1}\right)$. While in case of FYM application @ $7.5 \mathrm{tha^{-1 }}$ recorded significantly higher grain and straw yield (17.77 and $14.17 \mathrm{~g} \mathrm{pot}^{-1}$ ). Significantly higher nitrogen (495.53 and 755.37 mg pot $^{-1}$ ), phosphorus (66.43 and $111.23 \mathrm{mg} \mathrm{pot}^{-1}$ ) and potassium (285.12 and $96.41 \mathrm{mg} \mathrm{pot}^{-1}$ ) uptake was recorded with the application of phytase@3600 IU at 50 \% flowering and at harvest of soybean respectively. Similar uptake trend was observed for nitrogen (593.44 and $731.29 \mathrm{mg} \mathrm{pot}^{-1}$ ), phosphorus (72.90 and $110.08 \mathrm{mg} \mathrm{pot}^{-1}$ ) and potassium (321.94 and $105.47 \mathrm{mg}$ pot $\left.{ }^{1}\right)$ with the application of FYM @ $7.5 \mathrm{t} \mathrm{ha} \mathrm{a}^{-1}$ at $50 \%$ flowering and at harvest of soybean respectively.

KEYWORDS: Phytase, FYM, Soybean Growth, Yield, Nutrient Uptake \& Non Calcareous Soil
\end{abstract}

Received: Apr 04, 2020; Accepted: Apr 25, 2020; Published: May 29, 2020; Paper Id.: IJASRJUN20207

\section{INTRODUCTION}

Phosphorus is critically involved in energy production, transfer and storage of ATP for every biological process in nature. In plant, phosphorus is essential for photosynthesis, transpiration, respiration, energy, metabolism, synthesis of nucleic acids and membranes, nitrogen fixation, gene transfer, reproduction, root growth, flowering and root setting. Phosphorus is a major plant nutrient next to nitrogen in augmenting plant metabolic activity ultimately reflecting on the crop yield.

Soil phosphorus exists both in organic and inorganic form, the organic phosphorus compounds can be classified into i) the inositol phosphatase primarily of plant origin comprising up to $60 \%$ of soil organic phosphorus, ii) the nucleic acids and iii) phospholipids. In soils 20-85 per cent of the total phosphorus is in organic form but plants can only utilize this organic phosphorus after its mineralization. The availability of soil phosphorous 
(potential or applied) is largely governed by microflora and soil enzymes. Soil enzymes like acid and alkaline phosphatase and phytase are mainly involved in mineralization of fixed phosphorous. The acid phosphatase is predominant in acid soil and alkaline phosphatase is predominant in alkaline soil (Juma and Tabatabai 1987). The acid and alkaline phosphatase and phytase have an important role in mineralization of phosphorous in association with microbial population. Phytate is an organic form of phosphorus present in plant, soil and organic matter which is hydrolyzed by phytase enzyme. Phytase enzyme not only catalyzes the hydrolysis of organic form of phosphorus but also involved in improvement of other soil enzyme activities and microflora. Legumes secrete more phosphatase enzymes than cereals; this may be due to higher requirement of phosphorus by legumes especially soybean.

The soybean growing areas in Maharashtra are either of calcareous or black clayey soils. These soils are alkaline in nature $(8-8.5 \mathrm{pH})$ with moderate to high calcium carbonate content. The content of free calcium carbonate and clay content dominated soils are the main constraints for phosphorous availability. Both these constrains are attributed to the phosphorus fixation either by calcium as calcium phosphate or adsorption of phosphate ions on surface of clay, thereby resulting in lower recovery by crops \& buildup of its status in soil. A large proportion of phosphorus applied to soil as fertilizer rapidly becomes unavailable to plants due to fixation of inorganic phosphorus by adsorption and precipitation either with clay or $\mathrm{Ca}$ whereas, organic phosphorus fractions gets immobilized in soil organic matter. Hence the study the growth, nutrient uptake and yield of soybean as influenced by phytase enzyme and FYM levels in non-calcareous soil.

\section{MATERIALS AND METHODS}

A pot culture experiment was conducted at the Division of Soil science and Agriculture Chemistry, College of Agriculture, Pune, during Kharif 2014. The experiment consisted of sixteen treatment combinations based on four levels of phytase $(0,1200,2400$ and $3600 \mathrm{IU})$ and FYM $\left(0,2.5,5\right.$ and $\left.7.5 \mathrm{t} \mathrm{ha}^{-1}\right)$ replicated thrice in Factorial Completely Randomised Design. IU is the amount of enzyme that liberates $1 \mu \mathrm{mol}$ of inorganic orthophosphate from phytin per minute at $\mathrm{pH} 5.5$ and $37^{\circ} \mathrm{C}$. (Zyla et al., 1995). The initial soil and FYM analysis was carried by following standard methods (table 1).

The required quantity of black calcareous soil was collected from Agronomy farm, College of Agricultue, Pune. The quantity of FYM required for the experiment was procured from Division of Animal Husbandry and Diary Science, College of Agriculture, Pune. The phytase isolated from Aspergillus niger was obtained from National Collection of Industrial Microorganisms (NCIM), National Chemical Laboratory (NCL), Pune, India. The initial physico chemical and biochemical properties of soil were analyzed by using standard methods and presented in table 1. Forty eight earthen pots with $10 \mathrm{Kg}$ black calcareous soil were used during the experiment. Further another set of sixteen pots were maintained up to $50 \%$ flowering of soybean. Thereafter, pots were broken down to collect rhizospheral soil samples. Treatment wise required quantity of phyatse and FYM were thoroughly mixed with soil and sowing of soybean carried out. No phosphatic fertilizer was applied. However, recommended dose of nitrogen was supplied through urea.

Periodical yield and nutrient uptake was assessed at $50 \%$ flowering and harvest of soybean. The dry matter yield of soybean was taken for grain and straw by estimating their dry weight. Uptake of nutrients was determined by estimating the dry weight and nutrient concentration of soybean grain and straw separately. 
Table: 1: Initial Soil Fertility Status and FYM Composition

\begin{tabular}{|l|c|l|c|}
\hline \multicolumn{2}{|c|}{ Soil Fertility Status } & \multicolumn{2}{c|}{ FYM Composition } \\
\hline \multicolumn{1}{|c|}{ Soil Parameter } & Value & \multicolumn{1}{c|}{ FYM Parameter } & Value \\
\hline $\mathrm{pH}(1: 2.5)$ & 8.0 & Organic carbon $(\%)$ & 11.76 \\
\hline $\mathrm{EC}(1: 2.5)\left(\mathrm{dSm}^{-1}\right)$ & 0.29 & Total N $(\%)$ & 0.56 \\
\hline Organic carbon $(\%)$ & 0.70 & Total P $(\%)$ & 0.37 \\
\hline $\mathrm{CaCO}_{3}(\%)$ & 4.5 & Total K (\%) & 0.52 \\
\hline Available $\left(\mathrm{kg} \mathrm{ha}^{-1}\right)$ & 245 & C:N ratio & 21 \\
\hline Available P $\left(\mathrm{kg} \mathrm{ha}^{-1}\right)$ & 16.04 & C:P ratio & 31.78 \\
\hline Available K $\left(\mathrm{kg} \mathrm{ha}^{-1}\right)$ & 310 & & \\
\hline
\end{tabular}

\section{RESULTS AND DISCUSSIONS}

\section{Growth Attributes}

Plant morphological observations like plant height, root length, root-shoot ratio, fresh and dry weight of roots, number and weight of active root nodules at $50 \%$ flowering of soybean were significantly influenced by the application of phytase enzyme and FYM levels.(2a to $2 \mathrm{~g}$ )

Significantly higher mean plant height $(41 \mathrm{~cm})$ of soybean was reported with the application of 3600 IU phytase followed by 2400 and 1200 IU $\left(38 \mathrm{~cm}\right.$ ). However, application of FYM @ $7.5 \mathrm{t} \mathrm{ha}^{-1}$ reported significantly higher plant height $(43 \mathrm{~cm})$. Interaction effect between $3600 \mathrm{IU}$ phytase along with $7.5 \mathrm{t} \mathrm{ha}^{-1}$ reported significantly higher plant height $(46 \mathrm{~cm})$ than rest of the treatment. Data revealed that significantly higher root length at $50 \%$ flowering was recorded with the application of $3600 \mathrm{IU}$ phytase $(67 \mathrm{~cm})$ while FYM application @ $7.5 \mathrm{t} \mathrm{ha}^{-1}$ recorded $68 \mathrm{~cm}$. The combine application of phytase and FYM were found non-significant for root length but numerically higher root length $(74 \mathrm{~cm})$ recorded with the application of $3600 \mathrm{IU}$ phytase along with $7.5 \mathrm{t} \mathrm{ha}^{-1}$.

Significant and consistent increase in root-shoot ratio, fresh and dry weight of roots of soybean at $50 \%$ flowering was recorded with the application of phytase as well as FYM in non-calcareous soil. Significantly higher root-shoot ratio (1.66 and 1.68), fresh (7.92 and $8.43 \mathrm{~g}$ ) and dry weight of roots (5.57 and $6.15 \mathrm{~g}$ ) at 50\% flowering of soybean were recorded with the application of $3600 \mathrm{IU}$ phytase and $7.5 \mathrm{t} \mathrm{ha}^{-1} \mathrm{FYM}$.

In case of number and fresh weight of active root nodules at 50\% flowering of soybean were significantly influenced by phytase and FYM application. Significantly higher numbers of active root nodules were noticed with phytase @ $3600 \mathrm{IU}$ (62) and FYM $7.5 \mathrm{t} \mathrm{ha}^{-1}$ (65). However combine application of $3600 \mathrm{IU}$ phytase $+7.5 \mathrm{t} \mathrm{ha}^{-1} \mathrm{FYM}$ recorded higher number of active root nodules (77) than rest of the treatment. Application of phytase @ 3600 IU and FYM @ $7.5 \mathrm{t}$ $\mathrm{ha}^{-1}$ noted significantly higher fresh weight of active root nodules $(0.69$ and $0.66 \mathrm{~g})$. Numerically higher weight of active root nodules $(0.84 \mathrm{~g})$ was recorded with $3600 \mathrm{IU}$ phytase $+7.5 \mathrm{t} \mathrm{ha}^{-1} \mathrm{FYM}$.

The increase in plant height, root length, root-shoot ratio, root weight and nodule number might be ascribed to solubilisation of inorganic phosphorus by action of organic and inorganic acid secreted by microorganism and ultimately reduction in $\mathrm{pH}$ of soil which cause higher solubility (Yadav and Verma, 2012). Gujar et.al.,(2013) studied effect of phytase from Aspergillus niger on plant growth and mineral assimilation in wheat (Triticum aestivum Linn.) on calcareous soil and its potential for use as a soil amendment at NCL, Pune during 2012 and concluded that phytase isolated from Aspergillus niger promoted plant growth (upto $200 \%$ ). The length of root was higher in pots supplemented with phytase than uninoculated control. Vibha et al., 2014 studied impact of phosphorus solubilisation of fungi on yield of mung bean 
on sandy loam soil and concluded significantly higher root length with inoculation of Aspergillus niger strains No. 2. Tarafdar, (2008) conducted an experiment on mobilization of native phosphorus for plant nutrition at Central Arid Zone Research Institute, Jodhpur. He concluded that seed inoculation with Aspergillus fumigates and soil inoculation with Glomus mosseae increased root length. Muhammad Iqbal et al., (2013) concluded that phosphate solublizing bacteria enhance the growth (plant height, root length, dry weight of shoot and root) through simultaneous exudation of organic acids (by decreasing $\mathrm{pH}$ ) and/or through releasing phosphatases and ACC-deaminase. Tarafdar and Rao, (2001) reported that root nodulation of cluster bean was increased with inoculation of AMF + Rhizobium and FYM. This could be attributed to a more extensive root system, tapping a large volume of soil for water and nutrients.

\section{Grain Yield and Dry Matter Production}

The production of soybean dry matter at $50 \%$ flowering was ranged between 8.52 to $15.08 \mathrm{~g} \mathrm{pot}^{-1}$ (Table 3 and 4). Consistent increase in mean soybean dry matter was noticed either with application of FYM or phytase. Significantly higher mean dry matter was recorded with application of phytase @ $3600 \mathrm{IU}\left(12.86 \mathrm{~g} \mathrm{pot}^{-1}\right)$ followed by $2400 \mathrm{IU}$ (12.83 g pot $^{-1}$ ). Dry matter production of soybean was low in the pots where no phytase was applied. Application of FYM @ $7.5 \mathrm{t}$ $\mathrm{ha}^{-1}\left(14.08 \mathrm{~g} \mathrm{pot}^{-1}\right)$ recorded significantly higher mean soybean dry matter accumulation followed by FYM @ $5 \mathrm{t} \mathrm{ha}^{-1}$ (12.86 $\left.\mathrm{g} \mathrm{pot}^{-1}\right)$. At harvest, grain yield of soybean was influenced significantly by graded levels of phytase and FYM. Application of phytase@ $3600 \mathrm{IU}$ (17.34 $\left.\mathrm{g} \mathrm{pot}^{-1}\right)$ recorded significantly higher grain yield which was statistically at par with phytase @ $2400 \mathrm{IU}$ (17.28 $\left.\mathrm{g} \mathrm{pot}^{-1}\right)$. Similar trend of soybean was also reported for straw yield. Phytase application @ $3600 \mathrm{IU}$ recorded higher mean straw yield (14.31 $\left.\mathrm{g} \mathrm{pot}^{-1}\right)$ followed by $2400 \mathrm{IU}\left(13.74 \mathrm{~g} \mathrm{pot}^{-1}\right)$ and $1200 \mathrm{IU}\left(12.71 \mathrm{~g} \mathrm{pot}^{-1}\right)$. Application of graded levels of FYM significantly influenced grain yield of soybean. Significantly higher mean grain yield was noticed with application of FYM @ $7.5 \mathrm{t} \mathrm{ha}^{-1}\left(14.17 \mathrm{~g} \mathrm{pot}^{-1}\right)$.

Application of FYM had additive effect on dry matter production and seed yield. This could be attributed to a more extensive root system, tapping a large volume of soil for water and nutrients. Vibha et al., 2014 studied impact of phosphorus solubilisation of fungi on yield of mung bean on sandy loam soil and concluded significantly higher root length, dry weight and seed yield with inoculation of Aspergillus niger strains No. 2 which has more ability to secrete phytase. Tarafdar and Rao, (2001) reported that dry matter production of clusterbean was increased with inoculation of AMF + Rhizobium and FYM. Application of FYM had additive effect on dry matter production and seed yield. This could be attributed to a more extensive root system, tapping a large volume of soil for water and nutrients.

\section{Nutrient Uptake}

The major nutrient uptakes of soybean at $50 \%$ flowering were significantly influenced by various levels of phytase and FYM (Table 5 and 6). It was ranged between 238.03-643.93 $\mathrm{mg} \mathrm{pot}^{-1}, 10.26-29.64 \mathrm{mg} \mathrm{pot}^{-1}$ and 29.15-84.60 mg pot ${ }^{-1}$ for nitrogen, phosphorus and potassium respectively. The uptake of these nutrients was reported to be in increasing trend with either levels of phytase and FYM. Application of different levels of phytase recorded increasing trend for mean nitrogen, phosphorus and potassium uptake by soybean at 50\% flowering. Similar increasing trend with various levels of FYM was recorded for mean nitrogen, phosphorus and potassium. The major nutrient uptake viz. nitrogen, phosphorus and potassium by soybean at $50 \%$ flowering were significantly higher $495.53,66.43$ and $285.12 \mathrm{mg} \mathrm{pot}^{-1}$ with application of phytase @ $3600 \mathrm{IU}$ and $643.93,82.89$ and 321.94 with application of FYM respectively. 
The uptake of major nutrient namely, nitrogen, phosphorus and potassium were significantly influenced by phytase and FYM. Consistent increase in the uptake of nitrogen, phosphorus and potassium was observed with the graded levels of phytase from 0, 1200, 2400 and 3600 IU. Significantly higher (755.37 mg pot ${ }^{-1}$ ) uptake of nitrogen was noticed with application of 3600 IU phytase than rest of the treatment. However, application of phytase @ 3600 IU recorded statistically at par results for phosphorus $\left(111.23 \mathrm{mg} \mathrm{pot}^{-1}\right)$ and potassium $\left(96.41 \mathrm{mg} \mathrm{pot}^{-1}\right)$ uptake by soybean respectively. Similar trend was observed with the levels of FYM from 0, 2.5, 5, 7.5 t ha $\mathrm{a}^{-1}$. Application of FYM @ $7.5 \mathrm{t} \mathrm{ha}{ }^{-1}$ recorded significantly higher mean nitrogen, phosphorus and potassium uptake by soybean in non calcareous soil $(731.29,110.08$ and $\left.105.47 \mathrm{mg} \mathrm{pot}^{-1}\right)$.

Khan et al., 2013 found positive correlation ( $(\mathrm{r}=0.79)$ between dry matter yield and phosphorus uptake by rye grass in high clay textured soil with $61.8 \mathrm{~g} \mathrm{~kg}^{-1}$ organic carbon. Effect of inoculation with phosphatase producing fungi on dry matter production and grain yield of cluster bean, chickpea and wheat was studied by Tarafdar et al., 1995, Tarafdar and Rao 1996. They concluded higher nitrogen, phosphorus, potassium and calcium uptake by cluster bean, chickpea and wheat due to inoculation with phosphatase producing fungi. Gujar et al., 2013 concluded that phytase promoted phosphorus mineral assimilation much more efficiently as compared to chemical fertilizer.

\section{CONCLUSIONS}

Application of phytase @ 3600 IU, FYM @7.5 tha-1 and their related application was found superior for growth attributes of soybean at $50 \%$ flowering. However individual application or combine application of higher level of either phystae or FYM was found to be better for grain and straw yield and nutrient uptake of soybean at $50 \%$ flowering or at harvest.

\section{REFERENCES}

1. Gujar, P.D., Bhavsar, K.P, and Khire J.M. 2013. Effect of phytase from Aspergillus niger on plant growth and mineral assimilation in wheat (Triticum aestivum Linn.) and its potential for use on a soil amendment. Journal of Science, Food and Agriculture, 93, 2242-2247.

2. Halwankar, G.B., Raut, V.M., Taware S.P. and Patil, V.P. 1992. Production component study in soybean. Journal of Maharashtra Agricultural Universities. 17(3), 396-398.

3. Kale, F.S. 1985. Soybean, its value in dietetics, cultivation and uses. Published by International Books and Periodicals Supply Services, New Delhi. pp. 31-35.

4. Khan, Q.U., T.H. Flower and Sanaullah. 2013. Influence of soil phosphorus on enzyme activity, ryegrass yield and extractable phosphate. The journal of Animal and Plant Sciences, 23(1), 222-226.

5. Muhammad Iqbal Hussain, Hafiz Naeem Asghar, Muhammad Javed Akhtar and Muhammad Arshad. 2013. Impact of phosphate solubilizing bacteria on growth and yield of maize. Soil Environ. 32(1): 71-78.

6. Tarafdar, J.C. 2008. Mobilisation of nature phosphorus for plant nutrition, Journal of the Indian Society of soil science 56(4): 388-394.

7. Tarafdar, J.C. and Rao, A.V. 1996. Contribution of Aspergillus strains in Acquisition of phosphorus to wheat (Triticum aestivium, L.) and chickpea (Cicer arietinum L.) grown in a loamy sand soil. Applied Soil Ecology. 3(2), 109-114.

8. Tarafdar, J.C. and Rao, A.V. 2001 Response of clusterbean to Glomus mosseae and Rhizobium in an arid soil fertilized with nitrogen, phosphorus and Farmyard manure. Journal of the Indian Society of Soil Science 49 (4), 751-755

9. Tarafdar, J.C., Rao, A.V. and Kumar, P. 1995. Role of phosphate producing fungi on the growth and nutrition of Clusterbean 
(Cyamopsis tetragonoloba). Journal of Arid Environments, 29(3), 331-337.

10. Vibha, Geeta kumari and Nidhi. 2014. Impact of phosphate solubilizing fungi on the soil nutrient status and yield mung bean (Vigna radiate L) crop. Annals of Agricultural Research. New Series. 35(2), 136-143.

11. Yadav, B.K.; Verma, A. 2012. Phosphate solubilisation and Mobilization in soil through microorganisms under arid ecosystems, The Functioning of Ecosystems.

12. Zyla, K., D.R. Leudoux, and T.L. Veum. 1995. Complete enzymic dephosphorylation of corn-soybean meal feed under simulated intestinal conditions of the turkey. Journal of Agriculture Food Chemistry..43:288-294.

\section{Plant Height}

Table 2: Growth Attributes of Soybean at 50\% Flowering as Influenced by the Application of Phytase Enzyme and FYM in Non-Calcareous Soil

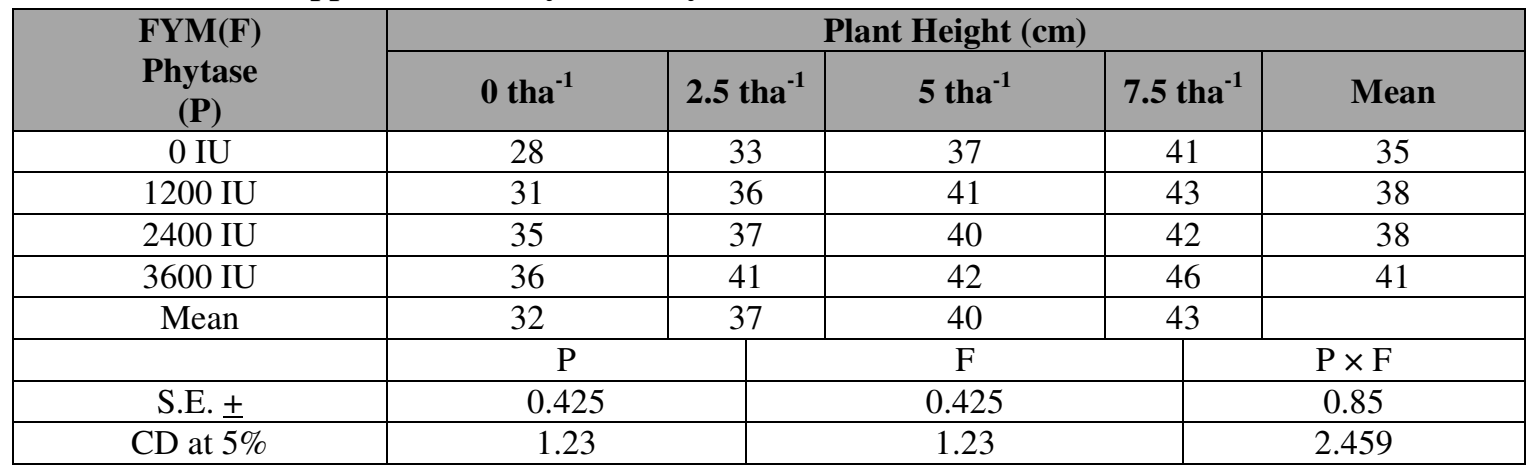

\section{Root Length}

\section{Root-Shoot Ratio}

\begin{tabular}{|c|c|c|c|c|c|}
\hline \multirow{2}{*}{$\begin{array}{c}\text { FYM } \\
\text { (F) } \\
\text { Phytase } \\
\text { (P) }\end{array}$} & \multicolumn{5}{|c|}{ Root Length (cm) } \\
\hline & 0 tha $^{-1}$ & 2.5 tha $^{-1}$ & 5 tha $^{-1}$ & 7.5 tha $^{-1}$ & Mean \\
\hline $0 \mathrm{IU}$ & 48 & 55 & 58 & 62 & 56 \\
\hline $1200 \mathrm{IU}$ & 52 & 57 & 60 & 68 & 59 \\
\hline $2400 \mathrm{IU}$ & 56 & 61 & 65 & 69 & 63 \\
\hline $3600 \mathrm{IU}$ & 58 & 66 & 69 & 74 & 67 \\
\hline \multirow[t]{2}{*}{ Mean } & 53 & 60 & 63 & 68 & \\
\hline & \multicolumn{2}{|l|}{$\mathrm{P}$} & \multicolumn{2}{|l|}{$\mathrm{F}$} & $P \times F$ \\
\hline S.E. \pm & \multicolumn{2}{|c|}{0.462} & \multicolumn{2}{|l|}{0.462} & 0.924 \\
\hline $\mathrm{CD}$ at $\overline{5 \%}$ & \multicolumn{2}{|c|}{1.337} & \multicolumn{2}{|l|}{1.337} & NS \\
\hline
\end{tabular}

\begin{tabular}{|c|c|c|c|c|c|}
\hline \multirow{2}{*}{$\begin{array}{c}\text { FYM } \\
\text { (F) } \\
\text { Phytase } \\
\text { (P) }\end{array}$} & \multicolumn{5}{|c|}{ Root-Shoot Ratio } \\
\hline & 0 tha $^{-1}$ & 2.5 tha $^{-1}$ & 5 tha $^{-1}$ & 7.5 tha $^{-1}$ & Mean \\
\hline $0 \mathrm{IU}$ & 1.49 & 1.48 & 2.37 & 1.70 & 1.76 \\
\hline $1200 \mathrm{IU}$ & 1.46 & 1.50 & 1.15 & 2.03 & 1.53 \\
\hline $2400 \mathrm{IU}$ & 1.65 & 1.43 & 1.69 & 1.28 & 1.51 \\
\hline $3600 \mathrm{IU}$ & 1.57 & 1.74 & 1.60 & 1.73 & 1.66 \\
\hline \multirow[t]{2}{*}{ Mean } & 1.54 & 1.54 & 1.70 & 1.68 & \\
\hline & \multicolumn{2}{|l|}{$\mathrm{P}$} & \multicolumn{2}{|l|}{$\mathrm{F}$} & $\mathrm{P} \times \mathrm{F}$ \\
\hline S.E. \pm & \multicolumn{2}{|c|}{0.044} & \multicolumn{2}{|l|}{0.044} & 0.088 \\
\hline CD at $5 \%$ & \multicolumn{2}{|c|}{0.127} & 0.127 & & 0.254 \\
\hline
\end{tabular}




\section{Fresh Weight of Roots}

Dry Weight of Roots

\begin{tabular}{|c|c|c|c|c|c|}
\hline \multirow{2}{*}{$\begin{array}{c}\text { FYM } \\
\text { (F) } \\
\text { Phytase } \\
\text { (P) }\end{array}$} & \multicolumn{5}{|c|}{ Fresh Weight of Roots (g) } \\
\hline & 0 tha $^{-1}$ & 2.5 tha $^{-1}$ & 5 tha $^{-1}$ & 7.5 tha $^{-1}$ & Mean \\
\hline $0 \mathrm{IU}$ & 5.53 & 6.38 & 7.44 & 8.01 & 6.84 \\
\hline $1200 \mathrm{IU}$ & 5.94 & 7.06 & 7.91 & 8.24 & 7.29 \\
\hline $2400 \mathrm{IU}$ & 6.79 & 7.31 & 7.94 & 8.60 & 7.66 \\
\hline $3600 \mathrm{IU}$ & 7.25 & 7.62 & 7.96 & 8.86 & 7.92 \\
\hline \multirow[t]{2}{*}{ Mean } & 6.38 & 7.09 & 7.81 & 8.43 & \\
\hline & \multicolumn{2}{|l|}{$\mathrm{P}$} & \multicolumn{2}{|l|}{$\frac{7.81}{\mathrm{~F}}$} & $\mathrm{P} \times \mathrm{F}$ \\
\hline S.E. \pm & \multicolumn{2}{|c|}{0.199} & \multicolumn{2}{|l|}{0.199} & 0.397 \\
\hline $\mathrm{CD}$ at $5 \%$ & \multicolumn{2}{|c|}{0.575} & 0.575 & & NS \\
\hline
\end{tabular}

\begin{tabular}{|c|c|c|c|c|c|}
\hline \multirow{2}{*}{$\begin{array}{c}\text { FYM } \\
\text { (F) } \\
\text { Phytase } \\
\text { (P) }\end{array}$} & \multicolumn{5}{|c|}{ Dry Weight of Roots (g) } \\
\hline & 0 tha ${ }^{-1}$ & 2.5 tha $^{-1}$ & 5 tha $^{-1}$ & 7.5 tha ${ }^{-1}$ & Mean \\
\hline $0 \mathrm{IU}$ & 3.24 & 4.10 & 5.16 & 5.73 & 4.56 \\
\hline $1200 \mathrm{IU}$ & 3.66 & 4.77 & 5.62 & 5.95 & 5.0 \\
\hline $2400 \mathrm{IU}$ & 4.50 & 5.34 & 5.66 & 6.32 & 5.46 \\
\hline $3600 \mathrm{IU}$ & 4.97 & 5.03 & 5.68 & 6.58 & 5.57 \\
\hline \multirow[t]{2}{*}{ Mean } & 4.09 & 4.81 & 5.53 & 6.15 & \\
\hline & \multicolumn{2}{|l|}{$\mathrm{P}$} & \multicolumn{2}{|l|}{$\mathrm{F}$} & $\mathrm{P} \times \mathrm{F}$ \\
\hline S.E. \pm & \multicolumn{2}{|c|}{0.17} & \multicolumn{2}{|l|}{0.17} & 0.34 \\
\hline $\mathrm{CD}$ at $5 \%$ & \multicolumn{2}{|c|}{0.492} & 0.492 & & $\frac{0.04}{N S}$ \\
\hline
\end{tabular}

\section{Number of Active Root Nodules}

\begin{tabular}{|c|c|c|c|c|c|}
\hline \multirow{2}{*}{$\begin{array}{c}\text { FYM } \\
\text { (F) } \\
\text { Phytase } \\
\text { (P) }\end{array}$} & \multicolumn{5}{|c|}{ Number of Active Root Nodules } \\
\hline & 0 tha $^{-1}$ & 2.5 tha $^{-1}$ & 5 tha $^{-1}$ & 7.5 tha $^{-1}$ & Mean \\
\hline $0 \mathrm{IU}$ & 33 & 43 & 48 & 56 & 45 \\
\hline $1200 \mathrm{IU}$ & 35 & 45 & 48 & 59 & 47 \\
\hline $2400 \mathrm{IU}$ & 40 & 51 & 54 & 70 & 54 \\
\hline $3600 \mathrm{IU}$ & 46 & 59 & 65 & 77 & 62 \\
\hline \multirow[t]{2}{*}{ Mean } & 38 & 49 & 54 & 65 & \\
\hline & \multicolumn{2}{|l|}{$\mathrm{P}$} & \multicolumn{2}{|l|}{$\mathrm{F}$} & $\mathrm{P} \times \mathrm{F}$ \\
\hline S.E. \pm & \multicolumn{2}{|c|}{0.529} & \multicolumn{2}{|l|}{0.529} & 1.057 \\
\hline $\mathrm{CD}$ at $5 \%$ & \multicolumn{2}{|l|}{1.53} & \multicolumn{2}{|l|}{1.53} & 3.06 \\
\hline
\end{tabular}

Fresh Weight of Active Root Nodules

\begin{tabular}{|c|c|c|c|c|c|}
\hline \multirow{2}{*}{$\begin{array}{c}\text { FYM } \\
(\mathbf{F}) \\
\begin{array}{c}\text { Phytase } \\
(\mathbf{P})\end{array}\end{array}$} & \multicolumn{5}{|c|}{ Fresh Weight of Active Root Nodules (g) } \\
\cline { 2 - 6 } & 0 tha $^{-\mathbf{1}}$ & $\mathbf{2 . 5}$ tha $^{-\mathbf{1}}$ & $\mathbf{5}$ tha $^{-1}$ & $\mathbf{7 . 5}$ tha $^{-1}$ & Mean \\
\hline $0 \mathrm{IU}$ & 0.28 & 0.31 & 0.33 & 0.35 & 0.32 \\
\hline $1200 \mathrm{IU}$ & 0.40 & 0.43 & 0.60 & 0.70 & 0.53 \\
\hline $2400 \mathrm{IU}$ & 0.44 & 0.52 & 0.65 & 0.75 & 0.59 \\
\hline $3600 \mathrm{IU}$ & 0.59 & 0.63 & 0.70 & 0.84 & 0.69 \\
\hline Mean & 0.43 & 0.47 & 0.57 & 0.66 & \\
\hline & \multicolumn{7}{|l}{$\mathrm{P}$} & $\mathrm{F}$ & $\mathrm{P} \times \mathrm{F}$ \\
\hline
\end{tabular}




\begin{tabular}{|c|c|c|c|}
\hline S.E. $\underline{+}$ & 0.022 & 0.022 & 0.043 \\
\hline CD at $5 \%$ & 0.063 & 0.063 & NS \\
\hline
\end{tabular}

Table 3: Dry Matter Production of SOYBEAN at 50\% Flowering as Influenced by the Application of Phytase Enzyme and FYM in Non-Calcareous Soil

\begin{tabular}{|c|c|c|c|c|c|}
\hline \multirow{2}{*}{$\begin{array}{c}\text { FYM } \\
\text { (F) } \\
\text { Phytase } \\
\text { (P) }\end{array}$} & \multicolumn{5}{|c|}{ Dry Matter $\left(\right.$ g Pot $\left.^{-1}\right)$} \\
\hline & 0 tha $^{-1}$ & 2.5 tha $^{-1}$ & 5 tha $^{-1}$ & 7.5 tha $^{-1}$ & Mean \\
\hline $0 \mathrm{IU}$ & 8.52 & 10.18 & 12.17 & 13.61 & 11.12 \\
\hline $1200 \mathrm{IU}$ & 9.49 & 11.58 & 12.84 & 13.19 & 11.77 \\
\hline $2400 \mathrm{IU}$ & 11.63 & 12.20 & 13.08 & 14.43 & 12.83 \\
\hline $3600 \mathrm{IU}$ & 11.11 & 11.93 & 13.34 & 15.08 & 12.86 \\
\hline \multirow[t]{2}{*}{ Mean } & 10.19 & 11.47 & 12.86 & 14.08 & \\
\hline & \multicolumn{2}{|l|}{$\mathrm{P}$} & \multicolumn{2}{|l|}{$\mathrm{F}$} & $\mathrm{P} \times \mathrm{F}$ \\
\hline S.E. \pm & 0.327 & & \multicolumn{2}{|l|}{0.327} & 0.654 \\
\hline $\mathrm{CD}$ at $\overline{5 \%}$ & \multicolumn{2}{|l|}{0.946} & \multicolumn{2}{|l|}{0.946} & NS \\
\hline
\end{tabular}

a. Grain yield:

Table 4: Grain and Straw Yield of Soybean as Influenced by the Application of Phytase Enzyme and FYM in Non-Calcareous Soil

\begin{tabular}{|c|c|c|c|c|c|}
\hline \multirow{2}{*}{$\begin{array}{c}\text { FYM } \\
\text { (F) } \\
\text { Phytase } \\
\text { (P) }\end{array}$} & \multicolumn{5}{|c|}{ Grain $\left(\right.$ g Pot $\left.^{-1}\right)$} \\
\hline & 0 tha $^{-1}$ & 2.5 tha $^{-1}$ & 5 tha $^{-1}$ & 7.5 tha $^{-1}$ & Mean \\
\hline $0 \mathrm{IU}$ & 14.33 & 15.32 & 16.44 & 15.55 & 15.41 \\
\hline $1200 \mathrm{IU}$ & 15.37 & 16.41 & 16.81 & 18.21 & 16.70 \\
\hline $2400 \mathrm{IU}$ & 15.91 & 17.02 & 17.55 & 18.65 & 17.28 \\
\hline $3600 \mathrm{IU}$ & 15.89 & 16.91 & 17.89 & 18.68 & 17.34 \\
\hline \multirow[t]{2}{*}{ Mean } & 15.37 & 16.41 & \multirow{2}{*}{\multicolumn{2}{|c|}{$\frac{11.11}{\mathrm{~F}}$}} & \multirow[b]{2}{*}{$\mathrm{P} \times \mathrm{F}$} \\
\hline & \multicolumn{2}{|l|}{$\mathrm{P}$} & & & \\
\hline S.E. + & \multicolumn{2}{|l|}{0.17} & \multicolumn{2}{|l|}{0.17} & 0.341 \\
\hline $\mathrm{CD}$ at $5 \%$ & \multicolumn{2}{|l|}{0.493} & \multicolumn{2}{|l|}{0.493} & NS \\
\hline
\end{tabular}

\section{b. Straw Yield}

\begin{tabular}{|c|c|c|c|c|c|}
\hline \multirow{2}{*}{$\begin{array}{c}\text { FYM } \\
\text { (F) } \\
\text { Phytase } \\
\text { (P) }\end{array}$} & \multicolumn{5}{|c|}{ Straw $\left(\right.$ g Pot $\left.^{-1}\right)$} \\
\hline & 0 tha $^{-1}$ & 2.5 tha $^{-1}$ & 5 tha $^{-1}$ & 7.5 tha $^{-1}$ & Mean \\
\hline $0 \mathrm{IU}$ & 12.37 & 12.42 & 13.44 & 13.68 & 12.98 \\
\hline $1200 \mathrm{IU}$ & 12.58 & 12.45 & 12.32 & 13.51 & 12.71 \\
\hline $2400 \mathrm{IU}$ & 13.25 & 13.39 & 13.65 & 14.67 & 13.74 \\
\hline $3600 \mathrm{IU}$ & 13.81 & 14.30 & 14.30 & 14.84 & 14.31 \\
\hline \multirow{2}{*}{ Mean } & 13.00 & 13.14 & 13.43 & & \\
\hline & \multicolumn{2}{|l|}{$\mathrm{P}$} & \multicolumn{2}{|r|}{\begin{tabular}{l|l}
14.17 \\
\end{tabular}} & $\mathrm{P} \times \mathrm{F}$ \\
\hline S.E. \pm & \multicolumn{2}{|l|}{0.059} & \multicolumn{2}{|c|}{0.059} & 0.118 \\
\hline $\mathrm{CD}$ at $5 \%$ & \multicolumn{2}{|l|}{0.17} & 0.17 & & 0.341 \\
\hline
\end{tabular}


Table 5: Effect of Phytase and FYM Levels on Nitrogen,

Phosphorus and Potassium Uptake of Soybean at 50 Percent Flowering

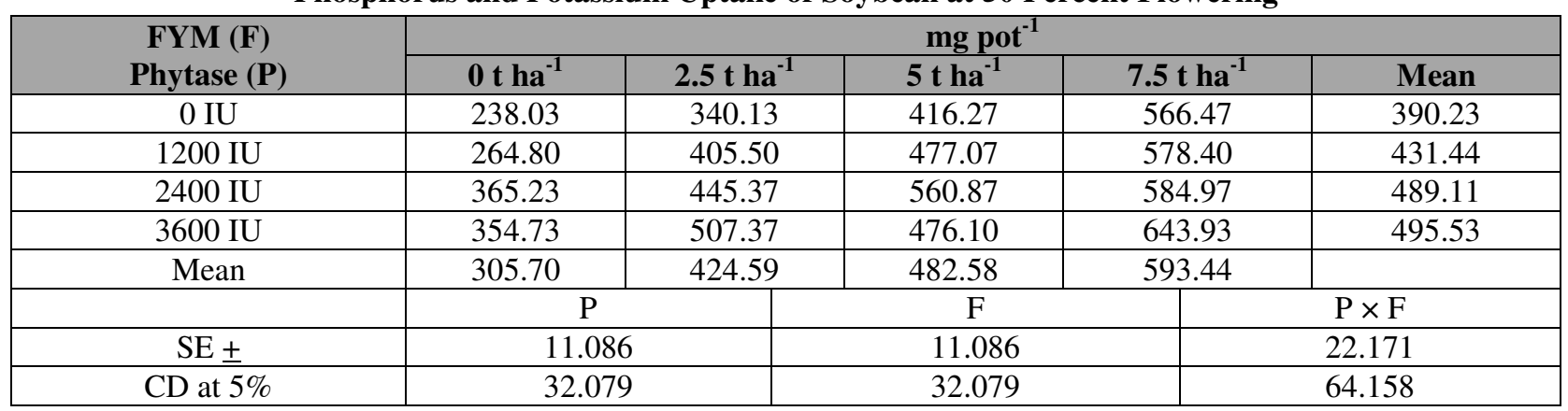

II). Phosphorus Uptake

\begin{tabular}{|c|c|c|c|c|c|}
\hline \multirow{2}{*}{$\begin{array}{c}\text { FYM (F) } \\
\text { Phytase (P }\end{array}$} & \multicolumn{5}{|c|}{$\mathrm{mg} \mathrm{pot}^{-1}$} \\
\hline & $0 \mathrm{tha}^{-1}$ & $2.5 \mathrm{t} \mathrm{ha}^{-1}$ & $5 \mathrm{tha}^{-1}$ & $7.5 \mathrm{tha}^{-1}$ & Mean \\
\hline $0 \mathrm{IU}$ & 29.10 & 42.67 & 60.13 & 66.61 & 49.63 \\
\hline $1200 \mathrm{IU}$ & 36.35 & 47.81 & 59.18 & 69.81 & 53.29 \\
\hline $2400 \mathrm{IU}$ & 52.07 & 60.05 & 62.07 & 72.27 & 61.62 \\
\hline $3600 \mathrm{IU}$ & 53.64 & 55.22 & 73.98 & 82.89 & 66.43 \\
\hline \multirow[t]{2}{*}{ Mean } & 42.79 & 51.44 & 63.84 & 72.90 & \\
\hline & \multicolumn{2}{|c|}{$\mathrm{P}$} & \multicolumn{2}{|l|}{$\mathrm{F}$} & \\
\hline $\mathrm{SE} \pm$ & & & 1.811 & \multicolumn{2}{|c|}{3.623} \\
\hline $\mathrm{CD}$ at $5 \%$ & \multicolumn{2}{|c|}{5.242} & 5.242 & & $\frac{5.02 \mathrm{~J}}{10.483}$ \\
\hline
\end{tabular}

III). Potassium Uptake

\begin{tabular}{|c|c|c|c|c|c|}
\hline \multirow{2}{*}{$\begin{array}{c}\text { FYM (F) } \\
\text { Phytase (P) }\end{array}$} & \multicolumn{5}{|c|}{$\mathrm{mg} \mathrm{pot}^{-1}$} \\
\hline & 0 t ha $^{-1}$ & $2.5 \mathrm{t} \mathrm{ha}^{-1}$ & $5 \mathrm{tha}^{-1}$ & $7.5 \mathrm{t} \mathrm{ha}^{-1}$ & Mean \\
\hline $0 \mathrm{IU}$ & 135.85 & 228.40 & 282.84 & 303.85 & 237.74 \\
\hline $1200 \mathrm{IU}$ & 173.11 & 221.71 & 258.55 & 298.64 & 238.00 \\
\hline $2400 \mathrm{IU}$ & 194.29 & 222.67 & 280.50 & 330.51 & 256.99 \\
\hline $3600 \mathrm{IU}$ & 242.21 & 250.97 & 292.56 & 354.75 & 285.12 \\
\hline \multirow[t]{2}{*}{ Mean } & 186.37 & 230.94 & 278.61 & 321.94 & \\
\hline & \multicolumn{2}{|c|}{$\mathrm{P}$} & \multirow{2}{*}{\multicolumn{2}{|c|}{$\frac{F}{7.183}$}} & $\mathrm{P} \times \mathrm{F}$ \\
\hline $\mathrm{SE} \pm$ & \multicolumn{2}{|c|}{7.183} & & & 14.366 \\
\hline $\mathrm{CD}$ at $5 \%$ & \multicolumn{2}{|c|}{20.786} & \multicolumn{2}{|l|}{20.786} & NS \\
\hline
\end{tabular}

I) Nitrogen uptake:

Table 6: Effect of Phytase and FYM Levels on Nitrogen, Phosphorus and Potassium Uptake of Soybean (Grain) at Harvest

\begin{tabular}{|c|c|c|c|c|c|}
\hline \multirow{2}{*}{$\begin{array}{c}\text { FYM (F) } \\
\text { Phytase (P) }\end{array}$} & \multicolumn{5}{|c|}{$\mathrm{mg}_{\text {pot }}{ }^{-1}$} \\
\hline & 0 t ha ${ }^{-1}$ & $2.5 \mathrm{tha}^{-1}$ & $5 \mathrm{tha}^{-1}$ & $7.5 \mathrm{t} \mathrm{ha}^{-1}$ & Mean \\
\hline $0 \mathrm{IU}$ & 534.08 & 587.77 & 602.18 & 689.09 & 603.28 \\
\hline $1200 \mathrm{IU}$ & 570.20 & 655.96 & 659.04 & 697.74 & 645.74 \\
\hline $2400 \mathrm{IU}$ & 676.87 & 712.55 & 716.34 & 780.81 & 721.64 \\
\hline $3600 \mathrm{IU}$ & 711.26 & 750.77 & 801.95 & 757.50 & 755.37 \\
\hline \multirow[t]{2}{*}{ Mean } & 623.10 & 676.76 & 694.88 & 731.29 & \\
\hline & \multicolumn{2}{|c|}{$\mathrm{P}$} & \multicolumn{2}{|l|}{$\mathrm{F}$} & \\
\hline $\mathrm{SE} \pm$ & \multicolumn{2}{|c|}{4.029} & \multirow{2}{*}{\multicolumn{2}{|c|}{$\begin{array}{r}4.029 \\
11.659\end{array}$}} & \\
\hline CD at $5 \%$ & & & & & $\begin{array}{c}8.058 \\
23.318\end{array}$ \\
\hline
\end{tabular}




\section{II). Phosphorus Uptake}

\begin{tabular}{|c|c|c|c|c|c|c|}
\hline \multirow{2}{*}{$\begin{array}{c}\text { FYM (F) } \\
\text { Phytase (P) }\end{array}$} & \multicolumn{6}{|c|}{$\mathrm{mg} \mathrm{pot}^{-1}$} \\
\hline & 0 t ha $^{-1}$ & $2.5 \mathrm{t} \mathrm{ha}^{-1}$ & $5 \mathrm{tha}^{-1}$ & \multicolumn{2}{|c|}{$7.5 \mathrm{t} \mathrm{ha}^{-1}$} & Mean \\
\hline $0 \mathrm{IU}$ & 50.42 & 78.31 & 84.94 & \multicolumn{2}{|c|}{97.20} & 77.72 \\
\hline $1200 \mathrm{IU}$ & 68.36 & 88.03 & 94.83 & \multicolumn{2}{|l|}{99.84} & 87.77 \\
\hline $2400 \mathrm{IU}$ & 83.67 & 88.80 & 95.78 & \multicolumn{2}{|l|}{115.18} & 95.86 \\
\hline $3600 \mathrm{IU}$ & 97.17 & 97.72 & 121.96 & \multicolumn{2}{|l|}{128.08} & 111.23 \\
\hline \multirow[t]{2}{*}{ Mean } & 74.91 & 88.21 & 99.38 & 110.08 & & \\
\hline & \multicolumn{2}{|l|}{$\mathrm{P}$} & \multicolumn{2}{|c|}{$\mathrm{F}$} & \multicolumn{2}{|l|}{$\mathrm{P} \times \mathrm{F}$} \\
\hline $\mathrm{SE} \pm$ & \multicolumn{2}{|l|}{3.958} & 3.958 & & \multicolumn{2}{|l|}{7.915} \\
\hline $\mathrm{CD}$ at $5 \%$ & \multicolumn{2}{|l|}{11.452} & 11.452 & & \multicolumn{2}{|l|}{22.905} \\
\hline
\end{tabular}

\section{III). Potassium Uptake}

\begin{tabular}{|c|c|c|c|c|c|}
\hline \multirow{2}{*}{$\begin{array}{c}\text { FYM (F) } \\
\text { Phytase (P) }\end{array}$} & \multicolumn{5}{|c|}{$\mathrm{mg} \mathrm{Pot}^{-1}$} \\
\hline & 0 t ha $^{-1}$ & $2.5 \mathrm{t} \mathrm{ha}^{-1}$ & $5 \mathrm{tha}^{-1}$ & $7.5 \mathrm{t} \mathrm{ha}^{-1}$ & Mean \\
\hline $0 \mathrm{IU}$ & 50.69 & 52.58 & 70.32 & 101.63 & 68.81 \\
\hline $1200 \mathrm{IU}$ & 62.87 & 65.16 & 79.21 & 94.54 & 75.45 \\
\hline $2400 \mathrm{IU}$ & 69.08 & 82.98 & 95.95 & 111.00 & 89.75 \\
\hline $3600 \mathrm{IU}$ & 74.66 & 92.87 & 103.39 & 114.72 & 96.41 \\
\hline \multirow[t]{2}{*}{ Mean } & 64.33 & 73.40 & 87.22 & 105.47 & \multirow[b]{2}{*}{$\mathrm{P} \times \mathrm{F}$} \\
\hline & \multicolumn{2}{|c|}{$P$} & \multicolumn{2}{|l|}{$\mathrm{F}$} & \\
\hline $\mathrm{SE} \pm$ & \multicolumn{2}{|c|}{0.674} & \multicolumn{2}{|l|}{0.674} & 1.347 \\
\hline $\mathrm{CD}$ at $5 \%$ & \multicolumn{2}{|c|}{1.949} & \multicolumn{2}{|l|}{1.949} & 3.898 \\
\hline
\end{tabular}

